\title{
Efforts to Curb NOx from Greenhouse Gases by the Application of Energy Crops and Vegetation Filters
}

\author{
Zsuzsa A. Mayer, Andreas Apfelbacher and Andreas Hornung
}

Additional information is available at the end of the chapter

http://dx.doi.org/10.5772/50624

\section{Introduction}

Nitrogen, in a similar way to carbon, has a complex and fragile global cycle. Anthropogenic activities from the beginning of the $20^{\text {th }}$ century have interfered with this fine nitrogenbalance by capturing $\mathrm{N}_{2}$ from the atmosphere for fertiliser production. When stable $\mathrm{N}$ from the atmosphere enters the forage crop production and stock-raising cycle it returns to the environment as waste and in more reactive forms.

During the combustion of energy crops the fuel-bound $\mathrm{N}$ forms greenhouse gases which are liberated to the atmosphere, therefore both fertiliser applications and biomass combustion can be directly linked to nitrogen related environmental problems.

Short-rotation plantations irrigated with effluent have both high nitrogen uptake capacity [1] and also enhance growth characteristics without the application of fertilisers or competition with fresh water usage $[2,3]$. Furthermore wastewater irrigation ${ }^{1}$ reduces the cost of wastewater treatment while crops cultivated on the land can provide solution for the increasing energy demand of rural areas without destroying existing forestry [2].

In order to choose appropriate feedstock and design a biomass-to-energy conversion technology both the economical and environmental aspect of a project should be considered. Biomass pyrolysis, which is the thermal degradation of the biomass in an inert atmosphere, provides an advanced liquid fuel. Pyrolysis liquid (or bio-oil) is the subject of intense research and investigations for direct energy applications to provide green electric power with highest efficiency [4].

${ }^{1}$ Throughout this chapter, the term wastewater will refer either to treated wastewater (effluent) or untreated (raw) wastewater. Wastewater irrigation can refer to both flood irrigation, spray irrigation, subsurface drains and other applications. 
This chapter introduces the use of energy crops into the global nitrogen-cycle by following nitrogen from wastewater irrigation via energy conversion (biomass pyrolysis) and finally back to soil in a stable form to close the circle (Fig. 1).

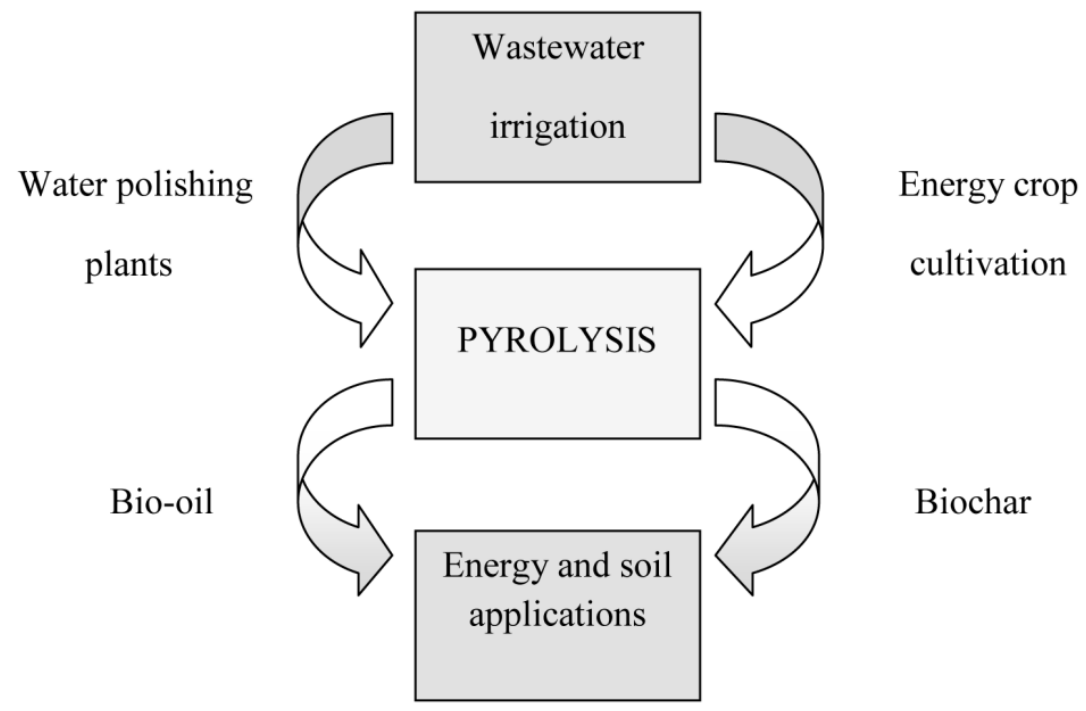

Figure 1. General scheme showing the conversion of wastewater irrigated vegetation filters to energy and to soil amendment

\section{Wastewater and wastewater treatments}

\subsection{Nitrogen in municipal wastewater}

Nitrogen in domestic wastewater is present in both inorganic and organic forms. Organic nitrogen from human diet and metabolism is transformed into free ammonia $\left(\mathrm{NH}_{3}\right)$ and ammonium cation $\left(\mathrm{NH}_{4}+\right)$ by microorganism $[5,6]$ The $\mathrm{NH}_{3}$ to $\mathrm{NH}_{4}{ }^{+}$ratio in water is depending on temperature and $\mathrm{pH}$. The presence of free $\mathrm{NH}_{3}$ above the concentration of $0.002 \mathrm{mg} / \mathrm{L}$ is toxic for the ecosystem [7]. Ammonia is also the source of inorganic nitrate and nitrite $\left(\mathrm{NO}_{3}{ }^{-}, \mathrm{NO}_{2}^{-}\right)$ nitrogen in wastewater [6]. Inorganic nitrogen is an essential plant nutrient. However, high concentrations in water cause eutrophication; an extreme bloom in the population of plants with an enhanced growth period followed by the necrosis of the biomass. The degradation of dead plant tissues increases oxygen demand of fresh water, therefore, eutrophication leads to oxygen scarcity and decreased self-cleaning ability of the biomass system [8]. The presence of nitrate and nitrite anions in drinking water is blamed for causing cyanotic conditions like shortness of breath, methemoglobinemia and blue-baby syndrome $[9,10]$.

To protect human health and aquatic life the nitrogenous contaminants of wastewater must be controlled. Table 1 contains some requirements set up by different governments and some typical nitrogen values in different types of wastewater. 


\begin{tabular}{|c|c|c|c|}
\hline & Form of nitrogen & $\begin{array}{c}\text { Concentration } \\
(\mathrm{mg} \mathrm{N} / \mathrm{L})\end{array}$ & Source \\
\hline $\begin{array}{l}\text { Typical nitrogen concentration in grey } \\
\text { wastewater }\end{array}$ & $\mathrm{TN}^{\mathrm{a}}$ & $0.6-74$ & [11] \\
\hline $\begin{array}{l}\text { Typical nitrogen concentrations in } \\
\text { domestic raw wastewater }\end{array}$ & $\mathrm{TN}$ & $20-80$ & [11] \\
\hline $\begin{array}{l}\text { Requirement of the European Council } \\
\text { for urban wastewater treatment }\end{array}$ & $\mathrm{TN}$ & 10 & [12] \\
\hline $\begin{array}{l}\text { Primary standards of the National } \\
\text { Primary Drinking Water Regulations by } \\
\text { US EPA }^{\mathrm{b}}\end{array}$ & Nitrate-N & 10 & [13] \\
\hline $\begin{array}{l}\text { Health value of the Australian Drinking } \\
\text { Water Guidelines }\end{array}$ & Nitrate-N & 11.3 & {$[14]$} \\
\hline
\end{tabular}

Table 1. Typical nitrogen values and requirements in water and wastewater

\subsection{Biological wastewater treatment}

The physicochemical removal of nitrogen from wastewater is possible, however, biological methods have proved to be more effective and less expensive treatments [15].

The biological removal of nitrogen is based on the mixed populations of live bacteria naturally present in wastewater which are able to convert nitrogen compounds to other chemical forms. The mineralization (consecutive steps of ammonification, nitrification and denitrification) of the wastewater-derived organic matter provides oxygen, nitrogen and energy for the bacteria to produce new cells [16].

The activated sludge formed by these living microorganisms is the core of modern industrial wastewater treatment technologies. To ensure the most suitable environmental conditions for the microorganisms (e.g. aerobic zone for nitrification and anoxic zone for denitrification) several industrial processes have been designed like the Bio-Denitro process, modified Ludzack-Ettinger process, Bardenpho process, etc. [15].

When these conventional wastewater treatment facilities are not available - mostly in developing countries - stabilization ponds are the most widely used municipal wastewater treatment systems [17]. Even if the climate favours microbial activity these stabilization ponds cannot reduce the concentration of nitrogen satisfactorily [18].

\subsection{Vegetation filters}

If the high cost of the commercial technologies discounts the use of sufficient wastewater treatment, the unregulated or poorly regulated water turns to a potential risk factor to human health and environment $[19,20]$. To eliminate this risk it is crucial to reduce the concentration of nitrogen and other pollutants before any effluent reaches the environment. 
The application of biological filter systems like soil and vegetation filters represents an alternative on-site wastewater treatment. While the first pilot tests were carried out by big companies to treat cannery effluents, the treatment of municipal water receives more and more attention now in developing countries [21,22]. This type of wastewater management is able to reduce the concentration of organic and inorganic contaminants in the water and remove $73-97 \%$ of the total nitrogen [23]. This low-cost treatment also assimilates nitrogen as plant nutrients back into the environment while pathogens from the wastewater cannot compete with the natural microbial population of the soil [24, 25].

\section{Nitrogen, the essential plant nutrient}

\subsection{Nitrogen in soil}

The role of soil in the biological-cycle is to store and supply nitrogen and other essential nutrients for plants. The average amount of organic nitrogen in soil is $3300 \mathrm{~kg} / \mathrm{ha}$, however, the available nitrogen for plants is less than $1 \%$ of the above volume as vegetations are not able to uptake any kind of forms of soil nitrogen [26].

\subsection{Nitrogen uptake in plants}

The synthesis of plant cell components (e.g. amino acids, nucleic acids, enzymes, chlorophyll etc.) is unachievable without nitrogen; nitrogen deficiency in plants causes slow growth which can be recognized by the pale green colour of the leaves. Without available nitrogen there are no processes in plants [26]. For the formation of new cells, plants uptake nitrogen - along with water - in the form of $\mathrm{NH}_{4}{ }^{+}$or $\mathrm{NO}_{3}{ }^{-}$during their growing period (assimilation), or store extra nitrogen (immobilization) [27].

Nitrogen is being absorbed from soil during the whole life of the plants but the nitrogen use efficiency of plants varies according to the stage of maturity, seasons, environmental conditions of the site and the fertility status of the soil as well [26, 28]. The latter factor is particularly important in terms of crop yield as nitrogen supply is a main limitation factor to plant growth [29].

\subsection{Synthetic nitrogenous fertilisers}

If the nitrogen supply within the soil is not sufficient, land productivity can be improved by organic and inorganic (also known as synthetic) macronutrient plant fertilisers. The most widely used synthetic fertilisers are ammonia-based products [30]. The source of nitrogen in these fertilisers is the atmosphere containing molecular nitrogen in $78 \%$. The direct reaction of molecular nitrogen and molecular hydrogen to $\mathrm{NH}_{3}$ is the base of the widely applied Haber-Bosch process [31] which provides more than 140 million tonnes of ammonia to farmers around the world every year [32].

Modern soil fertility management in the $20^{\text {th }}$ century has made a significant contribution to the growth of Earth's population which has almost quadrupled since 1900s. To sustain this 
growing population industry produces millions of tons of fertiliser which is responsible for more than $1 \%$ of the world's energy consumption. Since hydrocarbon combustion is the main energy source of ammonia production, the fertiliser industry is a major contributor to greenhouse gas emission [33]. In addition to the energy consumed during production transportation of the fertilisers is also contributing to the world's greenhouse gas emission with $37 \mathrm{Tg} \mathrm{CO}$-eq per year [34]. There is also an estimated 2.5-4.5 $\mathrm{Tg} \mathrm{N}$ emitted from the nitrogen-fertilised soil to the atmosphere each year [35].

\subsection{Nitrogen uptake in effluent-irrigated short-rotation crops}

If the cost or availability of the technology does not make it possible to apply inorganic fertilisers, alternative - and possibly more sustainable - nitrogen sources should be considered to increase the productivity of agricultural land.

Similar to inorganic fertilisers, wastewater is a source of supplemental nitrogen. According to studies, nitrogen uptake of rain-fed Eucalyptus in New Zealand is in the range of 30-80 $\mathrm{kg} / \mathrm{ha} /$ year while the uptake in effluent-irrigated plantations is one magnitude higher [1]. During wastewater irrigation, plants uptake nitrogen for their growth and polish the water. The absorbed $\mathrm{N}$ nutrients are converted to amino acids and stored in wood [36] or transferred from roots to shoots for protein synthesis [37]. Research results have also proved that plants have enhanced growing characteristics as a result of wastewater, grey water or effluent irrigation [38-40]. Table 2 shows the increments in storage and transport amino acid concentrations due to wastewater irrigation.

\begin{tabular}{l|ccccc}
$\begin{array}{l}\text { Free amino acid } \\
(\mu \mathrm{g} / \mathrm{mg})\end{array}$ & Arginine & Asparagine & $\begin{array}{c}\text { Aspartic } \\
\text { acid }\end{array}$ & Glutamine & $\begin{array}{c}\text { Glutamic } \\
\text { acid }\end{array}$ \\
\hline Control willow & 0.054 & 0.141 & 0.066 & 0.002 & 0.048 \\
Wastewater irrigated & 0.404 & 0.177 & 0.102 & 0.013 & 0.103 \\
willow & & & & &
\end{tabular}

Sample: Willow (Salix) from the bioremediation programme of Agri-Food \& Biosciences Institute (ABFI, Hillsborough, $\mathrm{N}$. Ireland). Trees were in their second year of re-growth after coppicing and plantations were irrigated with farm wastewater (TN: $100 \mathrm{mg} \mathrm{N} / \mathrm{L}$ ); Source: Chapter authors

Table 2. Free amino acid content of willow from wastewater irrigated plot and from a control plot

\subsection{Nitrate-leaching}

Even though vegetation has the potential to store wastewater-derived nitrogen, nutrient uptake is not the only limitation factor of the land applications of wastewater.

Due to the metabolism of microorganisms, nitrogen in soil and wastewater is predominantly present in the form of $\mathrm{NO}_{3}{ }^{-}$and $\mathrm{NH}_{4}{ }^{+}$, which are readily available plant nutrients. The surface charge of clay minerals in soil is negative which attaches the wastewater derived ammonium ion to soil matrix, but ions with negative charge are carried by water [41]. Due to heavy rains or improper agricultural activities nitrate nitrogen can leach below the root system of plants into the groundwater with a negative effect both on the environment and 
drinking water quality. Nitrate concentration in groundwater can reach extremely high values; one of the reported Indian examples was $1500 \mathrm{mg}$ nitrate in one litre of water, 150 times higher than the permitted value by the WHO [42].

Nitrate is a primary pollutant of groundwater. Although chemical reduction, biological denitrification and other in-situ treatments of groundwater are feasible [43], nitrate leaching is still the main limitation factor of wastewater irrigation; treatments cannot prevent the formation of groundwater contamination or solve the problem of nutrient loss of the soil. Without an effective prevention system the only groundwater protection is source control which means the limitation of wastewater loading.

\section{Energy from biomass}

\subsection{Heating values}

Treating contaminated water by vegetation filters require fast-growing plants, like willow [44]. Willow is also a widely cultivated fuelwood for energy applications with an annual yield of 9-13 t/ha in Europe [45].

An important feature of fuelwood and other energy crops is their composition which determines their heating (or calorific) value $[46,47]$. The higher heating value (HHV) is the energy available from the fuel and it is generally given in units of energy per unit of weight (cal/g; J/g or Btu/lb). Table 3 contains some typical heating values of fuelwood and other solid fuels. Energy crops can displace approximately 0.44 tonnes of oil equivalent when converted to electricity [48] and contribute to the reduction of greenhouse gas emission by 100-2070 Mt CO2-eq/year [49].

The quality characteristics of the biomass have a significant effect on the yield of energy during a biochemical or thermochemical conversion process [50]. For example high oxygen and carbon content favours combustion and increases the heating value [51] while the general model of heating values predicts a slight decrease in HHV when nitrogen content of biomass increases [52].

\begin{tabular}{lr|cc} 
& & HHV $\mathbf{~ M J / k g )}$ & Source \\
\hline Fuelwood & Softwood (average) & 20.0 & \\
& Hardwood (average) & 18.8 & {$[53]$} \\
Charcoals & Straw (maize silage) & 20.0 & {$[53]$} \\
& & & {$[49]$} \\
& Charcoal from rice husk & $17-18$ & {$[54]$} \\
Fossil fuels & "High quality" charcoal & $28-33$ & {$[55]$} \\
& & & \\
& General purpose coal & $32-42$ & {$[56]$}
\end{tabular}

Table 3. Heating values of energy crops, charcoals and fossil fuels 


\subsection{Biomass combustion and nitrogen liberation}

Nitrogen content of trees ranges between 0.3 and $1 \%$ [57]. Nitrogen in short-rotation plants is generally higher and significant differences can be found between species. Short-rotation plants represent a cheap and renewable energy source with high energy potential. The combustion of these plants is also a $\mathrm{CO}_{2}$ neutral energy conversion technology, however, combustion converts fuel-nitrogen to nitric oxides ( $\mathrm{NOx}=\mathrm{NO}+\mathrm{NO}_{2}$ ) and nitrous oxide $\left(\mathrm{N}_{2} \mathrm{O}\right)$ [58-63] which are contributors to acid rain formation [64]. $\mathrm{N}_{2} \mathrm{O}$ is also a greenhouse gas with a global warming potential (GWP) of 289 where 1 unit represents the global warming potential of $\mathrm{CO}_{2}$ over 20 years [65]. The emission of NOx contributes to acidification and it also causes eutrophication and ground-level ozone formation [66].

Increased nitrogen content in the biomass also means increased emission of NOx during combustion [67]. The estimated emission of NOx from biomass combustion was 5-5.9 TgN in 2000 [35] and based on the fact that the energy demand and the biomass fuel consumption are increasing [68], this NOx emission must be even more significant now and need to be decreased drastically.

To control the harmful effects of combustion plants' pollutants, organisations like Environmental Protection Agency of the United States (US EPA) or the Intergovernmental Panel on Climate Change (IPCC) have elaborated their guidelines and emission criteria [69, 70]. The most common way to fulfil these regulations is the application of flue gas cleaning systems (primary reduction with excess air, secondary catalytic reduction, etc) [67] but these technologies add cost, particularly in small bioenergy facilities. Another effective way to reduce the environment impact of biomass-derived NOx pollution is the application of alternative energy conversion technologies with better emission characteristics.

\section{Pyrolysis}

\subsection{Biomass conversion to solid, liquid and gas products}

Pyrolysis is a thermochemical process where the biomass (e.g. energy crop) is being converted into more effective energy sources. During the pyrolysis process the macromolecules and biopolymers of the biomass undergo a thermal degradation in the absence of oxygen, which leads to solid, liquid and gaseous products.

The thermal decomposition and conversion can be interpreted as the independent degradation of the three main organic woody biomass compounds, cellulose, hemicellulose and lignin [71, 72] which have an average ratio of 45/24/28 wt \% in softwood and 45/31/21 wt \% in hardwood, respectively [53]. The few parentage of wood inorganics remains in the solid product of pyrolysis while the lignocellulosic compounds undergo thermal degradation.

The biomass conversion at different pyrolysis temperatures can be followed by the thermal degradation and the weight loss of the main wood compounds on Fig. 2. The 
ratio of the gases, vapours and solid products depend on the temperature, residence time and heating rate of pyrolysis [73, 74]. Increasing the highest treatment temperature of pyrolysis increases the liquid and gas yields and decreases char yield (Fig 3). Due to secondary reactions of vapours liquid yield has a maximum which is followed by a reduction at higher temperatures and the gas yield increases at the expense of biochar yield $[73,75]$.

In terms of nitrogen oxide emission, pyrolysis is a more desirable energy conversion technology than combustion; while biomass combustion releases fuel-nitrogen in the form of NOx, the inert atmosphere of pyrolysis does not favour to the formation of these or any other oxidized pollutants [76].

\subsection{Pyrolysis liquids (bio-oil)}

Pyrolysis has the ability to generate highly energetic bio-oil which represents most of the energy content of wood (Fig. 4) with the additional benefit that it can be easily pumped or transported. Another advantage of the bio-oil from energy crops and vegetation filters is the lack of jeopardy to the security of food supply, unlike the dangers of sugar-, starchand vegetable oil-based conventional bio-fuels -which conquer valuable agriculture lands [77].

Bio-oil is still a relatively new energy source and its energy applications are still developing, but its combustion in boilers, turbines and engines has been successfully used for heat and electricity production $[78,79]$. Table 4 contains some typical power output values.

\section{Hot water generation}

Boiler fuelled with pyrolysis oil

$150 \mathrm{~kW}$

(BTG Biomass Technology Group BV, The Netherlands)

Electric power generation

Pyrolysis liquid combustion in diesel engine

$84 \mathrm{~kW}$

(VTT Energy, Finland)

Pyrolysis liquid combustion in diesel engine

$1.5 \mathrm{MW}$

(Wärtsilä Diesel International, Taiwan)

Pyrolysis liquid combustion in gas turbine

$75 \mathrm{~kW}$

(University of Rostock, Germany)

Combine heat and power generation (CHP)

Pyrolysis liquid combustion in a Stirling CHP unit

(ZSW, Germany)

(Source: Czernik, 2004)
$10-25 \mathrm{~kW}$ th,

4-9 kWe

Table 4. Power outputs from bio-oil combustion 


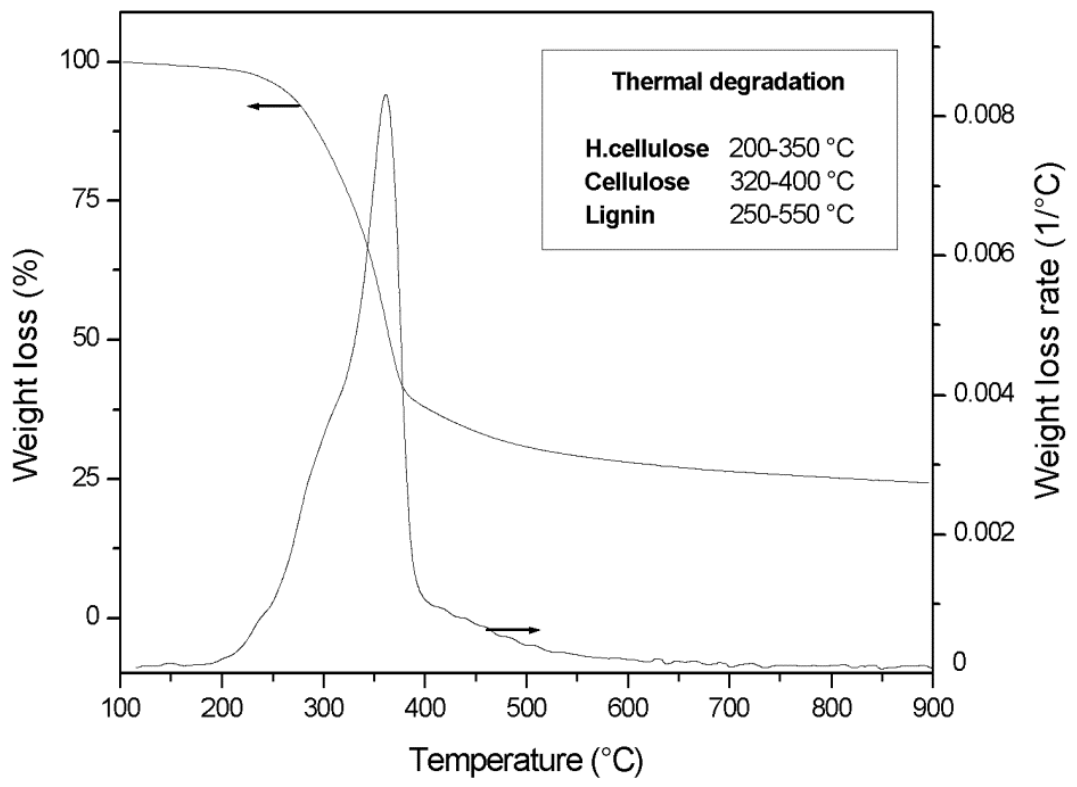

Sample: $10 \mathrm{mg}$ grinded willow (Salix) pyrolysed in a Mettler TGA/DSC 1 Star System. Heating rate: $20^{\circ} \mathrm{C} / \mathrm{min}$. Purging gas: He (Source: Chapter authors)

Figure 2. Typical thermal degradation curves of wood pyrolysis

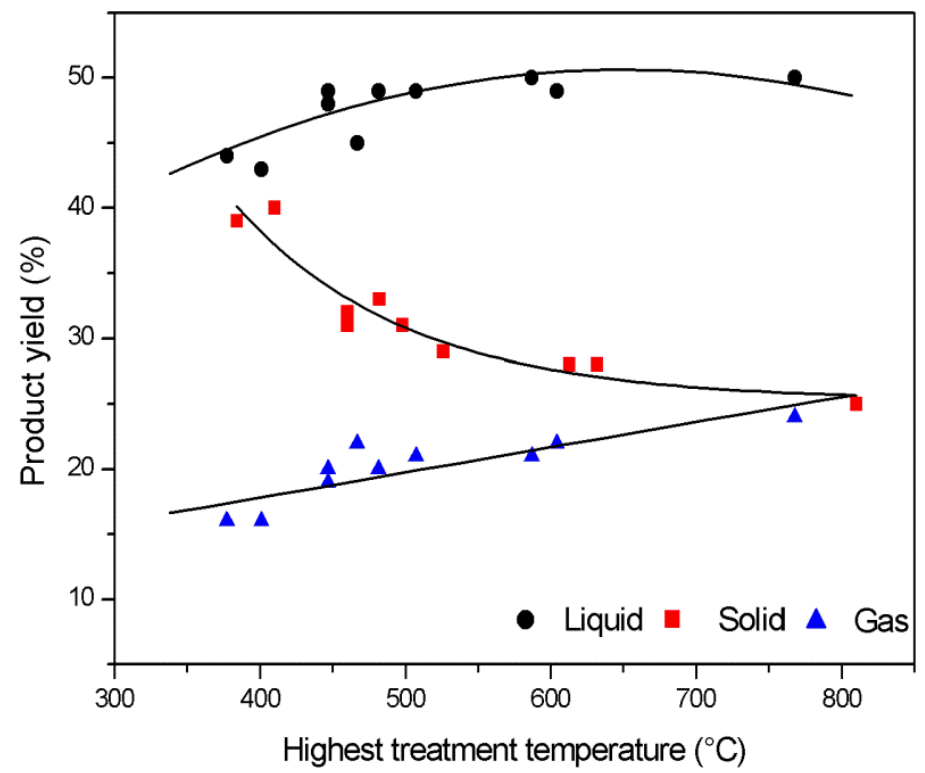

Sample: $100 \mathrm{~g}$ chipped willow (Salix) pyrolysed in a fixed bed reactor; Heating rate: $30^{\circ} \mathrm{C} / \mathrm{min}$, Purging gas: $\mathrm{N}_{2}$ (Source: Chapter authors)

Figure 3. Effect of pyrolysis temperature on product distribution 


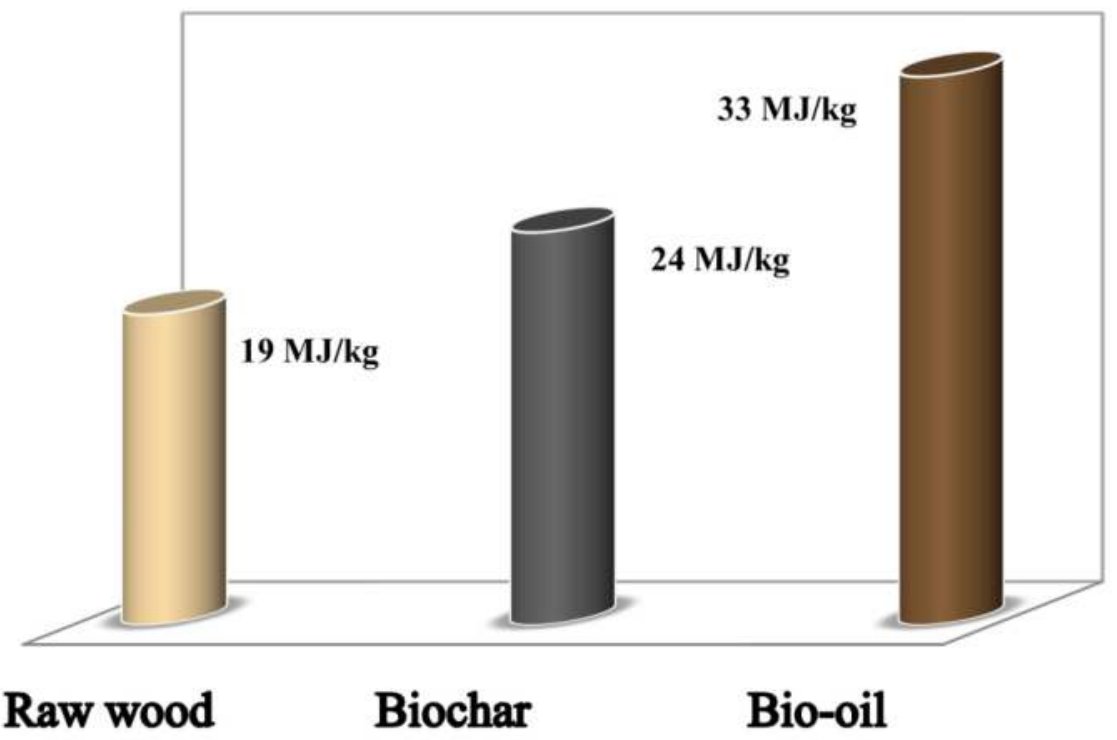

Raw material: $100 \mathrm{~g}$ chipped willow (Salix) pyrolysed in a fixed bed reactor Highest treatment temperature: $460{ }^{\circ} \mathrm{C}$, Purging gas: $\mathrm{N}_{2}$; Source: Chapter authors

Figure 4. Energy content of raw wood and its solid and liquid pyrolysis products

\subsection{Nitrogen in biochar and in pyrolysis gases}

Biochar and biomass char are the solid co-products of the pyrolysis process. They are mainly made of carbon and the ash content of the biomass. Despite of their similarities, historical definitions distinguish biochar from biomass char which is also known as charcoal. While the latter has been produced and used as fuel for heat for centuries, the former belongs to a new concept of soil management and carbon sequestration [80]. Other names like black carbon, dark earth (terra preta) or agrichar can be also fined in literature.

Enrichment of the fuel-bound nitrogen of biomass occurs in the biochar independently from the applied pyrolysis technique [81]. Nitrogenous gases (e.g. ammonia, hydrogen cyanide and isocyanic acid) are released during pyrolysis, but only at high temperature. The ration of these_main gaseous nitrogen products depending on both the type of biomass and the conditions of the pyrolysis process [76]. Nitrogen-free gases leave the system when pyrolysis temperature is increased which results nitrogen depletion in char at high temperatures [81]. However, low pyrolysis temperature does not favour the liberation of fuel nitrogen therefore most of the nitrogen (approximately $60-75 \%$ at $500{ }^{\circ} \mathrm{C}$ ) remains captured in the char $[72,76,82]$. 
The nitrogen functionalities in biochar are pyrrolic- $\mathrm{N}$, pyridinic- $\mathrm{N}$, quaternary- $\mathrm{N}$ and amines [83-85] and incubation tests evidenced that these stable nitrogen forms with low bioavailability [86].

\section{Biochar properties}

\subsection{Biochar as a fuel}

Due to its high fixed carbon content biochar is a renewable energy source with a heating value up to 30-35 MJ/kg [87]. Biomass char has higher energy density and better combustibility properties than traditional biomass, and higher reactivity than coal due to its oxygen content [88] and its incoherent carbon structure [89]. The combustion of biomass char is able to displace traditional fuels, however, the combustion of biochar recycles atmospheric $\mathrm{CO}_{2}$ and liberates the char-bond $\mathrm{N}$ in the form of NOx without the benefit of carbon or nitrogen sequestration.

According to different estimations biomass pyrolysis with soil applications of the biochar has a negative greenhouse gas emission - with a $\mathrm{CO}_{2}$ equivalent ranging from few hundred $\mathrm{kg}$ up to a few tonnes of $\mathrm{CO}_{2} e q t^{-1} d r y$ biomass - with a positive net energy [90-92]. A detailed calculation and complete life cycle assessment of biochar can be found in the work of Roberts at et al [90].

\subsection{Biochar as a soil amendment}

The most widely acknowledged benefit of biochar's soil applications is its long-term carbon sequestration potential $[90,93]$. Other potentials of biochar is stimulation of $\mathrm{N}_{2}$ fixation and the biological transformation of nitrogen in soil [94-96].

Biochar is also known for the ability to contribute to soil properties by changing its physical and chemical characteristics. The most important physicochemical properties of biochar are directly related to the type of the biomass used for char production and the applied temperature of pyrolysis $[55,97]$ therefore biochar contribution to soil quality factors can be both positive and negative [98, 99]. By selecting the right feedstock, setting the right pyrolysis conditions and elaborately characterising the physicochemical properties, char can be applied to soil as an amendment.

The pyrolysis temperature related structural changes of biochar can be seen on the infrared absorption spectra of Fig. 5. Comparing these spectra it can be seen that char gradually loses its structural complexity at higher pyrolysis temperatures as wood carbonisation becomes more completed. Char samples prepared at $300{ }^{\circ} \mathrm{C}$ and $400{ }^{\circ} \mathrm{C}$ show dramatic decreases in intensity in almost all functional groups; this is the temperature range in which the majority of the pyrolysis mass loss of wood occurs due to the degradation of cellulose, hemicellulose and lignin. Hemicellulose peak at $1736 \mathrm{~cm}^{-1}$ becomes undetectable in char prepared at $400{ }^{\circ} \mathrm{C}$ but the $\mathrm{O}-\mathrm{H}\left(3413 \mathrm{~cm}^{-1}\right)$ and $\mathrm{CH}_{\mathrm{n}}$ related vibrations $\left(2956,2924,2851 \mathrm{~cm}^{-1}\right)$ show dramatic decreases in char prepared at higher temperatures $\left(400-600{ }^{\circ} \mathrm{C}\right)$ where the thermal degradation of cellulose is already completed. Pyrogenic char (prepared at $700{ }^{\circ} \mathrm{C}$ or over) 
has no measured transmittance due to the lack of organic functionalities and the disordered carbon structure.

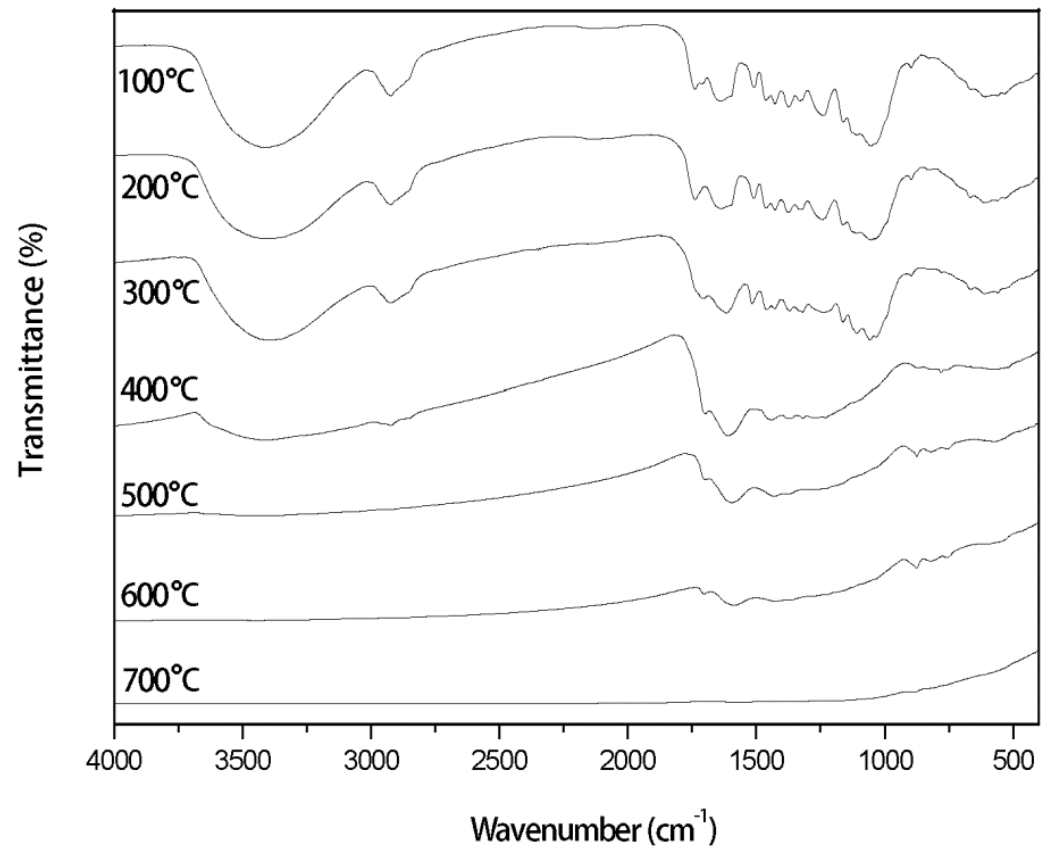

The first strong broad band between 3700 and $3000 \mathrm{~cm}^{-1}$ of dried willow $\left(100\right.$ and $\left.200{ }^{\circ} \mathrm{C}\right)$ is the stretching vibrations of $\mathrm{O}-\mathrm{H}$ functional groups. In the region of $2975-2840 \mathrm{~cm}^{-1}$ the unresolved group of medium weak bands is related to C $\mathrm{H}$ stretching vibrations of $\mathrm{CH}_{\mathrm{n}}$ groups. The peak at $1736 \mathrm{~cm}^{-1}$ is assigned to the absorption of free carbonyl groups, therefore it is a typical hemicellulose marker [112, 113]. Bands around 1600 and $1500 \mathrm{~cm}^{-1}$ are generally considered as lignin markers as this is the region of the skeletal vibrations of aromatic rings [114].

Sample: $2 \mathrm{mg}$ grinded wood or biochar blended with $200 \mathrm{mg} \mathrm{KBr}$ and pressed into pellet

Spectra: recorded on a Perkin Elmer Spectrum 100 FT-IR spectrometer, 4 scans per experiments, resolution: $4 \mathrm{~cm}^{-1}$ Source: Chapter authors

Figure 5. Changes in the infrared spectra of biochar obtained at different pyrolysis temperatures

The functional groups on biochar surface determine the $\mathrm{pH}$ and the cation exchange capacity and the nutrient retention in soil [100, 101]. The $\mathrm{pH}$ also has an impact on the mobility of ions and affects soil microbial activity [102].

As well as the changes of biochar surface, the increasing pyrolysis treatment temperature also increases $\mathrm{C}$ content, decreases $\mathrm{H}$ and $\mathrm{O}$ content and increases the ash content in char [103]. These changes in char composition increase hydrophobicity [99] and aromaticity [103]. Hydrophobicity and aromaticity play a major role in the future stability of biochar in soil [103] and the estimated half-life of char with O/C over 0.2 is $100-1000$ year and greater than 1000 years in case of char when $\mathrm{O} / \mathrm{C}$ is smaller than 0.2 [104].

The composition changes in the carbonised char is also accompanied by changes in the physical appearance of the biochar; Pyrolysis vapours can develop pores in biochar [105] 
The increased porosity affects the water-holding capacity of soil and the surface area - a shelter for microorganism [97]; bulk density, which affects the pore size distribution of soil and the conditions for gas exchange [106]; and total dissolved solids, which give an estimation on the amount of the mobile charged ions, migrating from char to soil [80].

Due to the high specific surface and adsorbent capacity, biochar can increase the water and nutrient retention capacity of the soil $[107,108]$ while a biochar buffer layer in soil can reduce both nitrate leaching and gaseous loss of soil nitrogen [107, 109]. Improved nitrogen recovery in soil will directly result in increased plant growth.

Biochar properties are strongly affected by the pyrolysis temperature $[97,110]$ which makes possible to design biochar, remediate specific soil issues and realise a new type of soil management $[99,111]$.

\section{Conclusions}

Nitrogen always has been the "weakest link" in the food chain and agriculture. Without additional nitrogen the present capacity of Earth's topsoil is not able to satisfy our hunger for biomass for food or energy.

Wastewater is a valuable source of nitrogen but nitrate leaching is harmful for groundwaters and results in nutrient lost from the soil. Plants cultivated for wastewater treatment can be considered as energy crops and bring land back into economic use.

To obtain an economically attractive feedstock for energy conversion applications, efforts should be made to maximise the utilisation of the sources (land, irrigation water etc) and the energy gained from the biomass with a minimum environmental impact. Pyrolysis of wastewater irrigated energy crops offers the advantages in both fields, therefore it is an excellent candidate to supply green energy for rural areas in developing countries while the soil application of biochar can retain and assimilate the wastewater derived nitrogen back into the environment.

- In terms of the nitrogen-cycle, biomass combustion liberates 5-5.9 Tg of NOx-N each year into the atmosphere. However, the cultivation of wastewater irrigated energy crops and the pyrolysis of the vegetation filters have the potential to reduce the emission of NOx-N and other greenhouse gases the following ways:

- Vegetation filters reduce the concentration of water contaminants and lower nitrogen content by $97 \%$. Wastewater can provide nitrogen and nutrients for plants and increase biomass yield without the application of inorganic soil fertilisers.

- Energy crops can uptake wastewater derived nitrogen and double the concentration of the storage amino acids.

- Compare to traditional combustion the pyrolysis of energy crops does not favour the formation of NOx.

- Pyrolysis captures $60-75 \%$ of the biomass derived nitrogen in the biochar. The soil applications of the biochar provide a long-term nitrogen sequestration and reduce the amount of the reactive nitrogen forms which accompany the traditional water treatment processes. 


\section{Author details}

Zsuzsa A. Mayer, Andreas Apfelbacher and Andreas Hornung

European Bioenergy Research Institute (EBRI), Aston University, Birmingham, United Kingdom

\section{Acknowledgement}

Financial support has been provided by the Science Bridge project (EP/G039992/1), the initiative of the Research Councils (RCUK) and Department of Science and Technology (DST). The authors are thankful for the permission to partly reproduce our paper, originally published in Z. A. Mayer, A. Apfelbacher and A. Hornung, "Nitrogen cycle of effluentirrigated energy crop plantations from wastewater treatment to the thermochemical conversion processes", Journal of Scientific and Industrial Research, 70, pages 675-682, Copyright 2011 NISCAIR.

\section{References}

[1] Nicholas I (2003) Nitrogen Uptake in New Zealand short Rotation Crops. Short Rotation Crops for Bioenergy: New Zealand. Crops 1985: 235-240.

[2] Pandey A, Srivastava R K (2010) Role of Dendropower in Wastewater Treatment and Sustaining Economy. Journal of Cleaner Production 18: 1113-1117.

[3] Vasudevan P, Thapliyal A, Srivastava R K, Pandey A, Dastidar M G, Davies P (2010) Fertigation Potential of Domestic Wastewater for Tree Plantations. Journal of Scientific \& Industrial Research 69: 146-150.

[4] Czernik S, Bridgwater A V (2004) Overview of Applications of Biomass Fast Pyrolysis Oil. Energy \& Fuels 18: 590-598.

[5] Patterson R A (2003) Nitrogen in Wastewater and its Role in Constraining On-site Planning in Future Directions for On-site Systems: Best Management Practice. Proceedings of On-site '03 Conference. University of New England, Armidale 30 Sept-2 Oct 2003. Published by Lanfax Laboratories Armidale. ISBN 0-9579438-1-4. pp 313-320.

[6] Abeliovich A (1992) Transformations of Ammonia and the Environmental Impact of Nitrifying Bacteria. Biodegradation 3: 255-264.

[7] US Environmental Protection Agency (1985). Ambient Water Quality Criteria for Ammonia. (440/5-85-001). EPA

[8] Oglesby R T, Edmondson W T (1966) Control of Eutrophication. Water Pollution Control Federation 38: 1452-1460.

[9] Knobeloch L, Salna B, Hogan A, Postle J, Anderson H (2000) Blue Babies and NitrateContaminated Well Water. Environmental Health Perspectives 108: 675-678.

[10] L'Hirondel J, L'Hirondel J L (2002) Nitrate and Man: Toxic, Harmless or Beneficial. Wallingford: CABI UK Publishing.

[11] Eriksson E, Auffarth K, Henze M, Ledin A (2002) Characteristics of Grey Wastewater. Urban Water 4: 85-104.

[12] European Commission (1991). Council directive of 21 May 1991 concerning urban waste water treatment. (91/271/EEC) EEC. Available from: http://eur-lex.europa.eu/ 
[13] US Environmental Protection Agency National Primary Drinking Water Regulations. EPA Available from: http://water.epa.gov/drink/contaminants/

[14] Australian Government National Health and Medical Research Council (1996). Australian Drinking Water Guidelines (ADWG). Available from: http://www.nhmrc.gov.au/

[15] Cooper P, Day M, Thomas V (1994) Process Options for Phosphorus and Nitrogen Removal from Wastewater. Water and Environment 8: 84-92.

[16] Verstraete W, Philips S (1998) Nitrification-Denitrification Processes and Technologies in New Contexts. Environmental Pollution 102: 717-726.

[17] von Sperling M (1996) Comparison Among the Most Frequently Used Systems for Wastewater Treatment in Developing Countries. Water Science and Technology 33: 59-72.

[18] Kivaisi A K (2001) The Potential for Constructed Wetlands for Wastewater Treatment and Reuse in Developing Countries: A Review. Ecological Engineering 16: 545-560.

[19] Corcoran E, C. N, Baker E, Bos R, Osborn, H. S (2010) Sick Water? The Central Role of Wastewater Management in Sustainable Development. A Rapid Response Assessment. United Nations Environment Programme, UN-HABITAT (Birkeland Trykkeri AS, Norway) 2010.

[20] Dixon A M, Butler D, Fewkes A (1999) Guidelines for Greywater Re-Use: Health Issues. Journal of the Chartered Institution of Water and Environmental Management 13: 322326.

[21] Gilde L C, Kester A S, Law J P, Neeley C H, Parmelee D M (1971) A spray Irrigation System for Treatment of Cannery Wastes. Journal of the Water Pollution Control Federation 43: 2011-2025.

[22] Bendixen T W, Hill R D, Dubyne F T, Robeck G G (1969) Cannery Waste Treatment by Spray Irrigation-Runoff. Water Pollution Control Federation 41: 385-391.

[23] Delgado A N, Periago E L, Viqueira F D-F (1995) Vegetated Filter Strips for Wastewater Purification: A Review. Bioresource Technology 51: 13-22.

[24] Bogosian G, Sammons L E, Morris P J L, Oneil J P, Heitkamp M A, Weber D B (1996) Death of the Escherichia Coli K-12 Strain W3110 in Soil and Water. Applied and Environmental Microbiology 62: 4114-4120.

[25] Toze S (1997) Microbial Pathogens in Wastewater. Literature Review for Urban Water Systems Multi-Divisional Research Program. Technical Report 1/97. CSIRO Land and Water, (Australia)

[26] Troeh, F. R.; Thompson, L. M. (2005) Soils and Soil Fertility, Oxford: Wiley-Blackwell

[27] Masclaux-Daubresse C, Daniel-Vedele F, Dechorgnat J, Chardon F, Gaufichon L, Suzuki A (2010) Nitrogen Uptake, Assimilation and Remobilization in Plants: Challenges for Sustainable and Productive Agriculture. Annals of Botany 105: 1141-1157.

[28] Gomez A, Leschber R, P. L H (1986) Sampling Problems for the Chemical Analysis of Sludge, Soils, and Plants. London and New York: Elsevier Applied Science Publishers.

[29] Vitousek P M, Howarth R W (1991) Nitrogen Limitation on Land and in the Sea: How Can It Occur? Biogeochemistry 13: 87-115.

[30] European Fertilizer Manufacturers' Association. Production of Urea and Urea Ammonium Nitrate. EFMA. Brussels, 2000. Available from: http://www.efma.org 
[31] Haber F, Le Rossignol R (1913) Über Die Technische Darstellung Von Ammoniak Aus Den Elementen. Zeitschrift für Elektrochemie und angewandte physikalische Chemie 19: 53-72.

[32] Manchester K L (2002) Man of Destiny: The Life and Work of Fritz Haber. Endeavour 26: 64-69.

[33] Wood S, Cowie, A, A Review of Greenhouse Gas Emission Factors for Fertiliser Production. In For IEA Bioenergy Task 38, International Energy Agency: 2004. Available from: http://www.ieabioenergy-task38.org

[34] International Fertilizer Industry Association Annual Production and International Trade Statistics. In: Series of Statistical Reports on 2007 Productio Capacity, Production and International Trade of Key Fertilizers, Raw Materials and Intermediates. IFA (2008) Paris, France

[35] Jaeglé L, Steinberger L, Martin R V, Chance K (2005) Global Partitioning of NOx Sources Using Satellite Observations: Relative Roles of Fossil Fuel Combustion, Biomass Burning and Soil Emissions. Faraday Discuss 130: 407-423.

[36] Haynes R, Goh K (1978) Ammonium and Nitrate Nutrition of Plants. Biological Reviews 53: 465-510.

[37] Dickson R (1989) Carbon and Nitrogen Allocation in Trees. Annales des Sciences Forestieres 46: 631-647.

[38] Chen G Z, Miao S Y, Tam N F Y, Wong Y S, Li S H, Lan C Y (1995) Effect of Synthethic Waster on Young Kandelia Candel Plants Growing under Greenhouse Conditions. Hydrobiologia 295: 263-273.

[39] Mohammad Rusan M J, Hinnawi S, Rousan L (2007) Long Term Effect of Wastewater Irrigation of Forage Crops on Soil and Plant Quality Parameters. Desalination 215: 143152.

[40] Mohammad Rusan M J, Mazahreh N (2003) Changes in Soil Fertility Parameters in Response to Irrigation of Forage Crops with Secondary Treated Wastewater. Communications in Soil Science and Plant Analysis 34: 1281 - 1294.

[41] Carroll D (1959) Ion Exchange in Clays and Other Minerals. Geological Society of America Bulletin 70: 749-779.

[42] Jacks G, Sharma V P (1983) Nitrogen Circulation and Nitrate in Groundwater in an Agricultural Catchment in Southern India. Environmental Geology 5: 61-64.

[43] Della Rocca C, Belgiorno V, Meriç S (2007) Overview of In-situ Applicable Nitrate Removal Processes. Desalination 204: 46-62.

[44] Meers E, Vandecasteele B, Ruttens A, Vangronsveld J, Tack F (2007) Potential of Five Willow Species (Salix Spp.) for Phytoextraction of Heavy Metals. Environmental and Experimental Botany 60: 57-68.

[45] Ericsson K, Rosenqvist H, Nilsson L J (2009) Energy Crop Production Costs in the EU. Biomass and Bioenergy 33: 1577-1586.

[46] Bech N, Jensen P A, Dam-Johansen K (2009) Determining the Elemental Composition of Fuels by Bomb Calorimetry and the Inverse Correlation of HHV with Elemental Composition. Biomass and Bioenergy 33: 534-537. 
[47] Thipkhunthod P, Meeyoo V, Rangsunvigit P, Kitiyanan B, Siemanond K, Rirksomboon $\mathrm{T}$ (2005) Predicting the Heating Value of Sewage Sludges in Thailand from Proximate and Ultimate Analyses. Fuel 84: 849-857.

[48] Aylott M J, Casella E, Tubby I, Street N, Smith P, Taylor G (2008) Yield and Spatial Supply of Bioenergy Poplar and Willow Short-Rotation Coppice in the UK. New Phytologist 178: 358-370.

[49] Sims R E H, Hastings A, Schlamadinger B, Taylor G, Smith P (2006) Energy Crops: Current Status and Future Prospects. Global Change Biology 12: 2054-2076.

[50] Kenney W A, Sennerby-Forsse L, Layton P (1990) A Review of Biomass Quality Research Relevant to the Use of Poplar and Willow for Energy Conversion. Biomass 21: 163-188.

[51] Gaur S, Reed T B (1998) An Atlas of The thermal Data For biomass and Other Fuels, Final Subcontract Report, New York: Marcel Dekker

[52] Channiwala S A, Parikh P P (2002) A Unified Correlation for Estimating HHV of Solid, Liquid and Gaseous Fuels. Fuel 81: 1051-1063.

[53] Demirbas A (1997) Calculation of Higher Heating Values of Biomass Fuels. Fuel 76: 431434.

[54] Demirbas A (1999) Properties of Charcoal Derived from Hazelnut Shell and the Production of Briquettes Using Pyrolytic Oil. Energy 24: 141-150.

[55] Antal M J, Grønli M (2003) The Art, Science, and Technology of Charcoal productionon. Industrial \& Engineering Chemistry Research 42: 1619-1640.

[56] Rose J W, Cooper J R (1977) Technical Data on Fuel. 7th edn London: British National Committee, World Energy Conference.

[57] Leppälahti J, Koljonen T (1995) Nitrogen Evolution from Coal, Peat and Wood During Gasification: Literature Review. Fuel Processing Technology 43: 1-45.

[58] Thompson D, Brown T D, Beér J M (1972) NOx Formation in Combustion. Combustion and Flame 19: 69-79.

[59] Fenimore C P (1971) Formation of Nitric Oxide in Premixed Hydrocarbon Flames. Symposium (International) on Combustion 13: 373-380.

[60] Kuo K K-Y (1986) Principles of Combustion. New York: Wiley.

[61] Nelson H F (1976) Nitric-Oxide Formation in combustion. AIAA Journal 14: 1177-1182.

[62] Leonard P A, Plee S L, Mellor A M (1976) Nitric Oxide Formation from Fuel and Atmospheric Nitrogen Combustion Science and Technology 14: 183-193.

[63] Hayhurst A N, Vince I M (1983) The Origin and Nature of "Prompt" Nitric Oxide in Flames. Combustion and Flame 50: 41-57.

[64] Likens G E, Bormann F H, Johnson N M (1972) Acid Rain. Environment: Science and Policy for Sustainable Development 14: 33-40.

[65] Elrod M J (1999) Greenhouse Warming Potentials from the Infrared Spectroscopy of Atmospheric Gases. Journal of Chemical Education 76: 1702-1705.

[66] Pitts J N (1993) Anthropogenic Ozone, Acids and Mutagens: Half a Century of Pandora's NOx. Research on Chemical Intermediates 19: 251-298.

[67] Nussbaumer T (1997) Primary and Secondary Measures for the Reduction of Nitric Oxide Emissions from Biomass Combustion. In: Bridgwater A V, Boocock D G B, 
editors. Development and Thermochemical Biomass Conversion. London: Chapman and Hall.

[68] Victor, N. M.; Victor, D. G., Macro Patterns in the Use of Traditional Biomass Fuels, in Stanford/TERI workshop on "Rural Energy Transitions", (New Delhi) 2002.

[69] US Environmental Protection Agency (1982). Air Quality Criteria for Oxides of Nitrogen. (600/8-82-026). EPA

[70] Intergovernmental Panel on Climate Change (2006). Guidelines for National Greenhouse Gas Inventories. IPCC Available from: http://www.ipcc-nggip.iges.or.jp

[71] Antal M J, Jr., Várhegyi G (1995) Cellulose Pyrolysis Kinetics: The Current State of Knowledge. Industrial \& Engineering Chemistry Research 34: 703-717.

[72] Skodras G, Natas P, Basinas P, Sakellaropoulos G P (2006) Effects of Pyrolysis Temperature, Residence Time on the Reactivity of Clean Coals Produced From Poor Quality Coals. Global NEST Journal 8: 89-94.

[73] Bridgwater A V, Meier D, Radlein D (1999) An Overview of Fast Pyrolysis of Biomass. Organic Geochemistry 30: 1479-1493.

[74] Bridgwater A V (1999) Principles and Practice of Biomass Fast Pyrolysis Processes for Liquids. Journal of Analytical and Applied Pyrolysis 51: 3-22.

[75] Di Blasi C, Branca C, D'Errico G (2000) Degradation Characteristics of Straw and Washed Straw. Thermochimica Acta 364: 133-142.

[76] Hansson K-M, Samuelsson J, Tullin C, Åmand L-E (2004) Formation of HNCO, HCN, and $\mathrm{NH}_{3}$ from the Pyrolysis of Bark and Nitrogen-Containing Model Compounds. Combustion and Flame 137: 265-277.

[77] Müller A, Schmidhuber J, Hoogeveen J, Steduto P (2008) Some Insights in the Effect of Growing Bio-Energy Demand on Global Food Security and Natural Resources. Water Policy 10: 83-94.

[78] Hornung A, Apfelbacher A, Richter F, Schneider D, Schöner J, Seifert H, Tumiatti V, Franchi P, Lenzi F, Haloclean - Intermediate Pyrolysis - Power Generation From Rape, 16th European Biomass Conference \& Exhibition, Valencia, Spain, 2008.

[79] Hossain A K, Davies P A (2010) Use of Pyrolysis Oil for CHP Application: Difficulties and Prospects. In: Proceedings of the World Renewable Energy Congress (WRECXI), Abu Dhabi, UAE, September 25-30, pp. 121-126.

[80] Joseph S, Peacocke C, Lehmann J, Munroe P (2009) Developing a Biochar Classification and Test Methods. In: Lehmann J, Joseph S, editors. Biochar for Environmental Management: Science and Technology. London: Earthscan. pp. 107-126.

[81] Johnsson J E (1994) Formation and Reduction of Nitrogen Oxides in Fluidized-Bed Combustion. Fuel 73: 1398-1415.

[82] Tan L L, Li C-Z (2000) Formation of NOx and SOx Precursors During the Pyrolysis of Coal and Biomass. Part I. Effects of Reactor Configuration on the Determined Yields of HCN and NH3 During Pyrolysis. Fuel 79: 1883-1889.

[83] Pels J R, Kapteijn F, Moulijn J A, Zhu Q, Thomas K M (1995) Evolution of Nitrogen Functionalities in Carbonaceous Materials During Pyrolysis. Carbon 33: 1641-1653. 
[84] Zhu Q, Money S L, Russell A E, Thomas K M (1997) Determination of the Fate of Nitrogen Functionality in Carbonaceous Materials During Pyrolysis and Combustion Using X-Ray Absorption Near Edge Structure Spectroscopy. Langmuir 13: 2149-2157.

[85] Gong B, Buckley A N, Lamb R N, Nelson P F (1999) XPS Determination of the Forms of Nitrogen in Coal Pyrolysis Chars. Surface and Interface Analysis 28: 126-130.

[86] Bridle T, Pritchard D (2004) Energy and Nutrient Recovery from Sewage Sludge Via Pyrolysis. Water Science and Technology 50: 169-175.

[87] Sharifi H (1999) A Methodology for Achieving Agility in Manufacturing Organisations: An Introduction. International Journal of Production Economics 62: 7-22.

[88] Backreedy R I, Jones J M, Pourkashanian M, Williams A Burn-out of Pulverised Coal and Biomass Chars. Fuel 82: 2097-2105.

[89] Henrich E, Bürkle S, Meza-Renken Z I, Rumpel S (1999) Combustion and Gasification Kinetics of Pyrolysis Chars from Waste and Biomass. Journal of Analytical and Applied Pyrolysis 49: 221-241.

[90] Roberts K G, Gloy B A, Joseph S, Scott N R, Lehmann J (2009) Life Cycle Assessment of Biochar Systems: Estimating the Energetic, Economic, and Climate Change Potential. Environmental Science \& Technology 44: 827-833.

[91] Gaunt J, Cowie A (2009) Greenhouse-gas Accounting and Emissions Trading. In: Lehmann J, Joseph S, editors. Biochar for Environmental Management: Science and Technology. London: Earthscan. pp. 317-340.

[92] Brownsort P, Carter S, Cook J, Cunningham C, Gaunt J, Hammond J, Ibarrola R, Sims K, Thornley $\mathrm{P}$ An assessment of the Benefits and Issues Associated with the Application of Biochar to Soil. Available from: http://www.biochar.org.uk

[93] Lehmann J, Czimczik C, Laird D, Sohi S (2009) Stability of Biochar in Soil. In: Lehmann J, Joseph S, editors. Biochar for Environmental Management: Science and Technology. London: Earthscan. pp. 183- 206.

[94] Sohi S P, Krull E, Lopez-Capel E, Bol R (2010) A Review of Biochar and Its Use and Function in Soil. In: Donald L S, editor. Advances in Agronomy. Academic Press. pp. 47-82.

[95] Lehmann J, da Silva J P, Steiner C, Nehls T, Zech W, Glaser B (2003) Nutrient Availability and Leaching in an Archaeological Anthrosol and a Ferralsol of the Central Amazon Basin: Fertilizer, Manure and Charcoal Amendments. Plant and Soil 249: 343-357.

[96] DeLuca T H, MacKenzie M D, Gundale M J (2009) Biochar Effects on Soil Nutrient Transformations. In: Lehmann J, Joseph S, editors. Biochar for Environmental Management: Science and Technology. London: Earthscan. pp. 251-270.

[97] Downie A, Crosky A, Munroe P (2009) Physical Properties of Biochar. In: Lehmann J, Joseph S, editors. Biochar for Environmental Management: Science and Technology. London: Earthscan. pp. 13-32.

[98] Shackley S, Sohi S, Brownsort P, Carter S, Cook J, Cunningham C, Gaunt J, Hammond J, Ibarrola R, Mašek O (2010) An Assessment of the Benefits and Issues Associated with the Application of Biochar to Soil. Department for Environment, Food and Rural Affairs (DEFRA), London, pp. 132. 
[99] Novak J M, Lima I, Xing B, Gaskin J W, Steiner C, Das K, Ahmedna M, Rehrah D, Watts D W, Busscher W J (2009) Characterization of Designer Biochar Produced at Different Temperatures and Their Effects on a Loamy Sand. Annals of Environmental Science 3: 195-206.

[100] Liang B L, Solomon J, Kinyangi D, Grossman J, O'Neill J, Skjemstad B, Thies J, Luizão J, Petersen F, Neves J (2006) Black Carbon Increases Cation Exchange Capacity in Soils. Soil Science Society of America 70: 1719-1730.

[101] Chan K Y, Xu Z (2009) Biochar: Nutrient Properties and Their Enhancement. In: Lehmann J, Joseph S, editors. Biochar for Environmental Management: Science and Technology. London: Earthscan. pp. 67-84.

[102] Thies J E, Rillig M C (2009) Characteristics of Biochar: Biological Properties. In: Lehmann J, Joseph S, editors. Biochar for Environmental Management: Science and Technology. London: Earthscan. pp. 85-106.

[103] Krull E S, Baldock J A, Skjemstad J O, Smernik R J (2009) Characteristics of Biochar: Organo-Chemical Properties. In: Lehmann J, Joseph S, editors. Biochar for Environmental Management: Science and Technology. London: Earthscan. pp. 53-65.

[104] Spokas K A (2010) Review of the Stability of Biochar in Soils: Predictability of O: C Molar Ratios. Carbon 1: 289-303.

[105] Cetin E, Moghtaderi B, Gupta R, Wall T F (2004) Influence of Pyrolysis Conditions on the Structure and Gasification Reactivity of Biomass Chars. Fuel 83: 2139-2150.

[106] Schjønning P, Thomsen I K, Petersen S O, Kristensen K, Christensen B T (2011) Relating Soil Microbial Activity to Water Content and Tillage-Induced Differences in Soil Structure. Geoderma 163: 256-264.

[107] Laird D, Fleming P, Wang B, Horton R, Karlen D (2010) Biochar Impact on Nutrient Leaching from a Midwestern Agricultural Soil. Geoderma 158: 436-442.

[108] Steiner C, Glaser B, Geraldes Teixeira W, Lehmann J, Blum W E, Zech W (2008) Nitrogen Retention and Plant Uptake on a Highly Weathered Central Amazonian Ferralsol Amended with Compost and Charcoal. Journal of Plant Nutrition and Soil Science 171: 893-899.

[109] Clough T J, Condron L M (2010) Biochar and the Nitrogen Cycle: Introduction. Journal of Environmental Quality 39: 1218-1223.

[110] Brewer C E, Schmidt-Rohr K, Satrio J A, Brown R C (2009) Characterization of Biochar from Fast Pyrolysis and Gasification Systems. Environmental Progress \& Sustainable Energy 28: 386-396.

[111] Mukherjee A, Zimmerman A R, Harris W (2011) Surface Chemistry Variations among a Series of Laboratory-Produced Biochars. Geoderma 163: 247-255.

[112] Owen N, Thomas D (1989) Infrared Studies of "Hard" and "Soft" Woods. Applied spectroscopy 43: 451-455.

[113] Yang H, Yan R, Chen H, Lee D H, Zheng C (2007) Characteristics of Hemicellulose, Cellulose and Lignin Pyrolysis. Fuel 86: 1781-1788.

[114] Schwanninger M, Rodrigues J C, Pereira H, Hinterstoisser B (2004) Effects of ShortTime Vibratory Ball Milling on the Shape of FT-IR Spectra of Wood and Cellulose. Vibrational Spectroscopy 36: 23-40. 